\title{
BINÁRIS IDŐBELI MULTIPLEXELÉSEN ALAPULÓ PERIODIKUS EGYFOTONFORRÁSOK OPTIMALIZÁLÁSA
}

\author{
Mechler Mátyás ${ }^{1}$, Bódog Ferenc ${ }^{1}$ és Ádám Péter ${ }^{1,2}$ \\ ${ }^{1}$ Pécsi Tudományegyetem, Természettudományi Kar, Fizikai Intézet, \\ H-7624 Pécs, Ifjúság útja 6. \\ ${ }^{2}$ Wigner Fizikai Kutatóközpont, Szilárdtestfizikai és Optikai Intézet, Kvantumoptika \\ és Kvantuminformatika Osztály, H-1121 Budapest, Konkoly-Thege Miklós út 29-33.
}

DOI: https://doi.org/10.14232/kvantumelektronika.9.27

\section{Bevezetés}

A periodikus egyfotonforrások fejlesztése egy jelenleg is intenzíven kutatott témaköre a kvantumoptikának. Az említett források fejlesztését számos lehetséges alkalmazásuk indokolja, melyek közül példaként említhető az optikai kvantumszámítás [1], kvantumkulcsszétosztás [2] és különböző kvantumoptikai kísérletek [3]. Több különböző fizikai rendszerre alapozva valósítottak már meg egyfotonforrásokat, ezek közül a leggyakrabban vizsgált rendszerek a spontán parametrikus lekonverzió (SPL) folyamatára épülő, korrelált fotonpárokat adó valószínúségi források. Ezekben az egyik foton (jelző foton) detektálásával időbeli és térbeli információt szerzünk a társfotonról, amelyet így felhasználhatunk.

Az említett berendezésekben térbeli [4-7] vagy idôbeli [8-11] multiplexeléssel érhetô el az ideálishoz közeli múködés. A multiplexelô rendszerekkel ideális esetben tökéletes periodikus egyfotonforrást kaphatnánk, azonban a multiplexelố rendszer méretével, az alkalmazott optikai elemek számával arányos veszteségek mindkét multiplexelő rendszerben lerontják a várt eredményt.

A [12] közleményünkben megadtuk a multiplexelésen alapuló periodikus egyfotonforrások statisztikai leírását, melynek segítségével több különböző multiplexelt egyfotonforrás optimalizálását végeztük el. A részletes statisztikai elemzésből kiderül, hogy mindkét multiplexelés esetében létezik optimális rendszerméret, amely mellett a berendezés a maximális egyfoton-valószínúséget adja. Javasoltunk továbbá egy bináris időbeli multiplexelésen alapuló forrást, amely az analízis szerint valós kísérleti paraméterek mellett jelenleg a legmagasabb egyfoton-valószínúséget adja. A [13] cikkünkben kiterjesztettük a leírásmódot kombinált multiplexelésen alapuló egyfotonforrásokra. Ezekben a rendszerekben egyaránt alkalmaznak térbeli, és időbeli multiplexelést. Mindkét említett publikációban küszöbdetektorokkal múködtetett egyfotonforrásokat vizsgáltunk, amelyek csak a fotonok jelenlétét rögzítik. A statisztikus leírást a [14]-es közleményünkben általánosítottuk fotonszámfeloldó detektorok esetére. Ezek a detektorok nemcsak a fotonok jelenlétét, hanem a detektált fotonok számát is képesek meghatározni. A részletes statisztikai elemzést szimmetrikus térbeli multiplexelésen alapuló egyfotonforrásokra végeztük el.

Ebben a kéziratban az általunk javasolt bináris időbeli multiplexelésen alapuló egyfotonforrás optimalizálását végezzük el abban az esetben, ha fotonszámfeloldó detektorokat alkalmazunk a jelző fotonok észlelésére. 


\section{Bináris idôbeli multiplexelés}

Az 1. ábra mutatja a bináris időbeli multiplexelésen alapuló egyfotonforrás sematikus ábráját. A fotonpárok SPL forrásban keletkeznek, melyet impulzusüzemú, vagy folytonos üzemú lézerrel gerjesztünk. Az SPL forrásból kilépő $i$-vel jelölt jelző fotonok a D-vel jelölt detektorra vannak vezetve. Az $s$-el jelölt jelfotonok $\tau_{0}$ késleltetés után lépnek be a multiplexerbe. A jelfotonokat a különböző $\tau$, $2 \tau, 4 \tau \ldots$ hosszúságú késleltetôutakba az $\mathrm{OS}_{n}$-el jelölt optikai kapcsolók vezetik be. Látható, hogy a késleltetések hossza kettő hatványai szerint növekszik, innen a bináris időbeli multiplexelés elnevezés. Az optikai kapcsolókat a $\mathrm{C}$ vezérlőegység konfigurálja a detektorból érkező információk alapján. Az idốbeli késleltetés során egy detektált fotonon annyit késleltetünk, hogy az előre meghatározott periódusidő végére lépjen ki a rendszerből.

A [12] közleményünkben javasoltunk egy hagyományos optikai eszközökből felépíthetô bináris időbeli multiplexelésen alapuló egyfotonforrást. A javasolt rendszerben a késleltetőegységek az 1. ábrán látható módon épülnek fel. Az optikai kapcsolót ebben a rendszerben a PC-vel jelölt Pockelscella, valamint a PBS-el jelölt polarizációs nyalábosztóval valósítjuk meg. A foton vertikális polarizációval érkezik a Pockels-cellához. A polarizáció megváltoztatásával vezethetjük be a fotont a késleltetôegységbe.
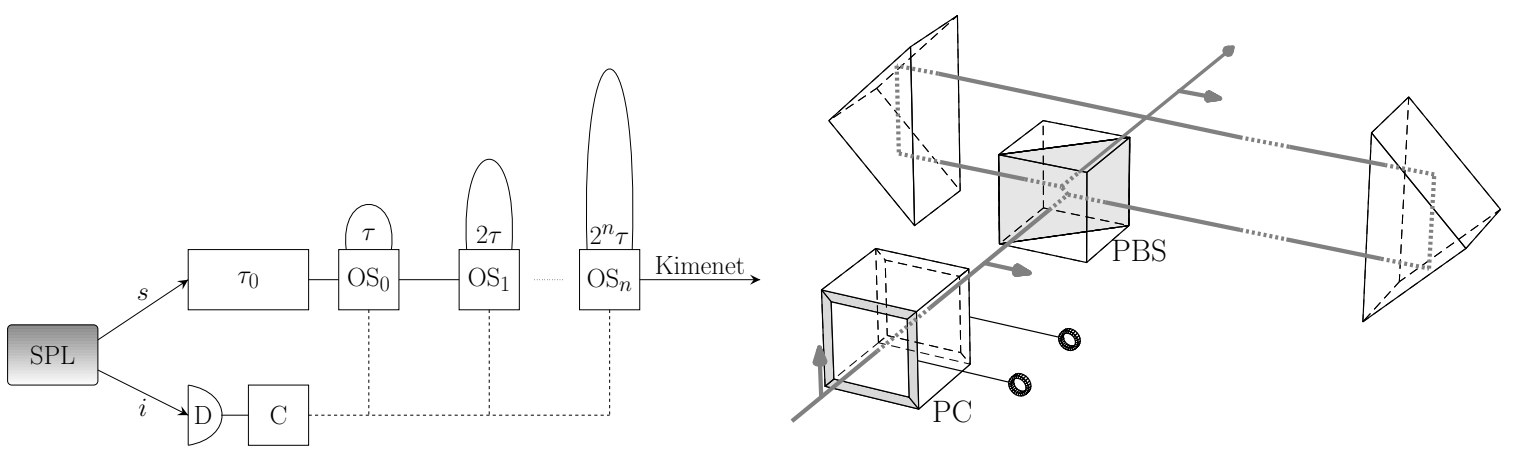

1. ábra. A bináris időbeli multiplexelés sematikus ábrája (balra). Hagyományos optikai elemekből felépíthetô késleltetőegység (jobbra). Jelölések: PC - Pockels-cella; PBS - polarizációs nyalábosztó; SPL - spontán parametrikus lekonverzió; OS - optikai kapcsoló; D - detektor; C - vezérlőegység.

\section{A multiplexelt egyfotonforrások statisztikai leírása}

Tekintsünk egy térben vagy időben multiplexelt egyfotonforrást, amelyben a multiplexelt egységek száma (nemlineáris források vagy időablakok száma) $N$. Tegyük fel, hogy az $n$-edik multiplexelt egységben $j$ fotonpár érkezik a nemlineáris forrásból, és a multiplexer bemenetein egy előre definiált $l$ detektált fotonszám esetén léphetnek be jelfotonok. Annak a valószínúsége, hogy a beérkezô $j$ foton közül $i$ éri el a forrás kimenetét, a következőképpen határozható meg [14]:

$$
\begin{aligned}
P_{i}^{(S)} & =\left(1-\sum_{l \in S} P^{(D)}(l)\right)^{N} \delta_{i, 0}+ \\
& +\sum_{n=1}^{N}\left[\left(1-\sum_{l \in S} P^{(D)}(l)\right)^{n-1} \times \sum_{l \in S} \sum_{j=\max (i, l)}^{\infty} P^{(D)}(l \mid j) P^{(\lambda)}(j) V_{n}(i \mid j)\right] .
\end{aligned}
$$

Az egyenletben $P^{(D)}(l)$ jelöli $l$ foton detektálásának valószínúségét, $P^{(D)}(l \mid j)$ jelöli azt a feltételes valószínúséget, hogy a detektor $l$ fotont észlel, feltéve, hogy $j$ foton érkezett a felületére, $P^{(\lambda)}(j)$ 
pedig $j$ fotonpár keletkezésének a valószínúségét jelöli. A $P^{(D)}(l)$ valószínúséget a következôképpen írhatjuk:

$$
P^{(D)}(l)=\sum_{j=l}^{\infty} P^{(D)}(l \mid j) P^{(\lambda)}(j)=\sum_{j=l}^{\infty}\left(\begin{array}{l}
j \\
l
\end{array}\right) V_{D}^{l}\left(1-V_{D}\right)^{j-l} P^{(\lambda)}(j),
$$

ahol $V_{D}$ a detektorhatásfok. A számításaink során a keletkező fotonpárok számát Poisson-eloszlásúnak feltételeztük. Az általános egyenletben megjelenő $V_{n}(i \mid j)$ kifejezés annak a valószínúsége, hogy $i$ foton éri el az egyfotonforrás kimenetét, feltéve, hogy az $n$-edik multiplexelt egységből $j$ foton érkezett, melyet az 1. ábrán bemutatott bináris időbeli multiplexelés esetén a következőképpen számíthatunk ki:

$$
V_{n}(i \mid j)=\left(\begin{array}{l}
j \\
i
\end{array}\right) V_{n}^{i}\left(1-V_{n}\right)^{j-i}, \quad \text { ahol } \quad V_{n}=V_{b} V_{\mathrm{re}}^{h} V_{t}^{l-h} V_{p}^{(N-n) / N} .
$$

A kifejezésben $V_{n}$ az $n$-edik időablakhoz tartozó transzmisszió valószínúsége, amelyben $V_{\text {re }}$ és $V_{t}$ a polarizációs nyalábosztók reflexiós és transzmissziós koefficiensei, $V_{p}$ a terjedéshez tartozó veszteség, amely tartalmazza a Pockels-cellán való áthaladáshoz tartozó veszteséget, $V_{b}$ pedig egy általános, időablaktól független veszteségi paraméter (fotonok összegyújtésének valószínúsége, becsatolási veszteség stb.), $h$ pedig $N-n$ Hamming-súlya.

Az általános kifejezésben az $S$ halmaz tartalmazza azokat az előre meghatározott fotonszámokat, amelyek rögzítése esetén a jelfotonok beléphetnek a multiplexerbe. Ez a halmaz egy detektálási stratégiát határoz meg, amelyet csak fotonszámfeloldó detektorokkal lehet megvalósítani. Ebben a munkában $S=\left\{1,2,3 \ldots, J_{\max }\right\}$ alakú detektálási stratégiákat veszünk figyelembe.

\section{Eredmények}

Ebben a szakaszban mutatjuk be az optimalizálás eredményeit. Az optimalizálás során elsőként rögzítjük az egyfotonforrást jellemző összes kísérleti paramétert és a detektálási stratégiát, kezdve $S=\{1\}$-el. Ezt követően a multiplexelt időablakok számát kettő hatványai szerint növelve, minden $N$ értékhez meghatározzuk a bemeneti fotonszám $\lambda_{\text {opt }}$ optimális átlagos értékét. A multiplexelt időablakok azon száma, amelyhez a legmagasabb egyfoton-valószínúség tartozik, az lesz az $N_{\text {opt }}$ optimális rendszerméret. Ezt követôen megismételjük az optimalizálást $S=\{1,2\}, S=\{1,2,3\}$... detektálási stratégiákat feltételezve. A különböző detektálási stratégiák mellett meghatározott egyfotonvalószínúségek abszolút maximuma adja meg az optimális detektálási stratégiát $\left(S_{\mathrm{opt}}\right)$.

Az optimalizálást kísérletileg elérhető paramétertartományokon végezzük. A polarizációs nyalábosztók reflexiós együtthatóját a $0.9 \leq V_{\text {re }} \leq 0.996$, a transzmissziós együtthatót pedig a $0.9 \leq V_{t} \leq$ 0.97 tartományon vizsgáljuk. A fotonszámfeloldó detektorok hatásfokát a $0.6 \leq V_{d} \leq 0.98$ tartományon vizsgáljuk. A terjedési veszteség értékét $V_{p}=0.95$ értéken rögzítjük, a $V_{b}$ általános veszteségi paramétert pedig egységnek vesszük, hiszen ez a rendszer kvalitatív tulajdonságait nem változtatja meg.

Az optimalizálás eredményeit az 1. táblázat tartalmazza. A táblázatban vizsgált tartományon az optimális detektálási stratégia végig $S=\{1\}$. A táblázatból látszik, hogy növekvő $V_{t}$ és $V_{\text {re }}$ értékekhez növekvő optimális rendszerméret tartozik, ugyanakkor az optimális bemeneti fotonszám értéke csökken. Amennyiben $N_{\text {opt }}$ értéke változatlan, az átlagos bemeneti fotonszám $V_{t}$ és $V_{\text {re }}$ növekvésével akkor is csökken, hiszen alacsonyabb veszteségek mellett a fotonok egyre kisebb valószínúséggel vesznek el a multiplexelő rendszerben. $N_{\text {opt }}$ ugrásakor $\lambda_{\text {opt }}$-ban is nagyobb ugrás van, hiszen ekkor kétszer annyi multiplexelt időablakból érkezhetnek fotonok. Ez nem más, mint a források multiplexelésének alapelve, azaz, hogy egy multiplexelt egységben a generált fotonpárok átlagos számának csökkentésével csökkentjük több fotonpár keletkezésének a valószínúségét, miközben a multiplexelt egységek számának növelésével azt a valószínúséget csökkentjük, hogy egyáltalán ne érkezzen foton. 


\begin{tabular}{|c|c|c|c|c|c|c|c|c|c|c|c|c|c|}
\hline \multirow{2}{*}{$V_{t}$} & \multirow[b]{2}{*}{$V_{\mathrm{re}}$} & \multicolumn{3}{|c|}{$V_{D}=0.6$} & \multicolumn{3}{|c|}{$V_{D}=0.8$} & \multicolumn{3}{|c|}{$V_{D}=0.9$} & \multicolumn{3}{|c|}{$V_{D}=0.98$} \\
\hline & & $N_{\mathrm{opt}}$ & $P_{1, \max }^{\mathrm{EFD}}$ & $\lambda_{\mathrm{opt}}$ & $N_{\text {opt }}$ & $P_{1, \text { max }}^{\mathrm{EFD}}$ & $\lambda_{\text {opt }}$ & $N_{\text {opt }}$ & $P_{1, \max }^{\mathrm{EFD}}$ & $\lambda_{\mathrm{opt}}$ & $N_{\mathrm{opt}}$ & $P_{1, \max }^{\mathrm{EFD}}$ & $\lambda_{\mathrm{opt}}$ \\
\hline & 0.90 & 16 & 0.587 & 0.490 & 8 & 0.635 & 0.751 & 8 & 0.660 & 0.818 & 8 & 0.680 & 0.950 \\
\hline & 0.92 & 16 & 0.615 & 0.476 & 8 & 0.659 & 0.735 & 8 & 0.688 & 0.808 & 8 & 0.713 & 0.947 \\
\hline & 0.94 & 16 & 0.643 & 0.463 & 8 & 0.683 & 0.719 & 8 & 0.717 & 0.798 & 8 & 0.746 & 0.944 \\
\hline & 0.96 & 32 & 0.672 & 0.296 & 16 & 0.719 & 0.465 & 8 & 0.746 & 0.787 & 8 & 0.781 & 0.942 \\
\hline & 0.98 & 32 & 0.714 & 0.290 & 16 & 0.757 & 0.461 & 16 & 0.785 & 0.551 & 8 & 0.816 & 0.939 \\
\hline & 0.99 & 32 & 0.735 & 0.287 & 16 & 0.776 & 0.459 & 16 & 0.808 & 0.553 & 16 & 0.840 & 0.841 \\
\hline & 0.996 & 64 & 0.749 & 0.220 & 32 & 0.791 & 0.344 & 16 & 0.821 & 0.553 & 16 & 0.856 & 0.843 \\
\hline \multirow[t]{7}{*}{0.92} & 0.90 & 16 & 0.599 & 0.461 & 8 & 0.645 & 0.725 & 8 & 0.671 & 0.790 & 8 & 0.693 & 0.936 \\
\hline & 0.92 & 16 & 0.628 & 0.451 & 8 & 0.669 & 0.711 & 8 & 0.699 & 0.782 & 8 & 0.725 & 0.935 \\
\hline & 0.94 & 16 & 0.656 & 0.440 & 16 & 0.696 & 0.433 & 8 & 0.729 & 0.774 & 8 & 0.759 & 0.933 \\
\hline & 0.96 & 32 & 0.691 & 0.271 & 16 & 0.734 & 0.434 & 8 & 0.758 & 0.765 & 8 & 0.794 & 0.932 \\
\hline & 0.98 & 32 & 0.733 & 0.268 & 16 & 0.772 & 0.433 & 16 & 0.801 & 0.503 & 8 & 0.830 & 0.929 \\
\hline & 0.99 & 64 & 0.757 & 0.183 & 32 & 0.794 & 0.294 & 16 & 0.823 & 0.508 & 16 & 0.855 & 0.794 \\
\hline & 0.996 & 64 & 0.774 & 0.184 & 32 & 0.810 & 0.296 & 16 & 0.837 & 0.510 & 16 & 0.871 & 0.800 \\
\hline \multirow[t]{7}{*}{0.94} & 0.90 & 16 & 0.612 & 0.436 & 8 & 0.655 & 0.699 & 8 & 0.682 & 0.760 & 8 & 0.705 & 0.918 \\
\hline & 0.92 & 16 & 0.641 & 0.428 & 8 & 0.679 & 0.687 & 8 & 0.711 & 0.755 & 8 & 0.738 & 0.920 \\
\hline & 0.94 & 16 & 0.670 & 0.420 & 16 & 0.711 & 0.404 & 8 & 0.740 & 0.749 & 8 & 0.772 & 0.920 \\
\hline & 0.96 & 32 & 0.711 & 0.250 & 16 & 0.749 & 0.407 & 16 & 0.772 & 0.446 & 8 & 0.808 & 0.919 \\
\hline & 0.98 & 64 & 0.754 & 0.155 & 32 & 0.789 & 0.250 & 16 & 0.817 & 0.460 & 8 & 0.844 & 0.918 \\
\hline & 0.99 & 64 & 0.783 & 0.157 & 32 & 0.816 & 0.255 & 16 & 0.840 & 0.466 & 16 & 0.870 & 0.726 \\
\hline & 0.996 & 64 & 0.801 & 0.158 & 32 & 0.832 & 0.258 & 16 & 0.854 & 0.469 & 16 & 0.886 & 0.738 \\
\hline \multirow[t]{7}{*}{0.96} & 0.90 & 16 & 0.625 & 0.414 & 8 & 0.665 & 0.674 & 8 & 0.693 & 0.731 & 8 & 0.717 & 0.896 \\
\hline & 0.92 & 16 & 0.654 & 0.408 & 8 & 0.690 & 0.664 & 8 & 0.723 & 0.729 & 8 & 0.751 & 0.901 \\
\hline & 0.94 & 32 & 0.689 & 0.233 & 16 & 0.727 & 0.379 & 8 & 0.752 & 0.725 & 8 & 0.786 & 0.904 \\
\hline & 0.96 & 32 & 0.732 & 0.234 & 16 & 0.766 & 0.383 & 16 & 0.789 & 0.408 & 8 & 0.821 & 0.905 \\
\hline & 0.98 & 64 & 0.783 & 0.138 & 32 & 0.811 & 0.223 & 16 & 0.834 & 0.423 & 16 & 0.859 & 0.591 \\
\hline & 0.99 & 64 & 0.813 & 0.140 & 32 & 0.839 & 0.228 & 16 & 0.857 & 0.429 & 16 & 0.886 & 0.630 \\
\hline & 0.996 & 128 & 0.833 & 0.089 & 64 & 0.856 & 0.146 & 32 & 0.875 & 0.265 & 16 & 0.902 & 0.650 \\
\hline \multirow[t]{7}{*}{0.97} & 0.90 & 16 & 0.632 & 0.403 & 8 & 0.670 & 0.662 & 8 & 0.699 & 0.717 & 8 & 0.723 & 0.883 \\
\hline & 0.92 & 16 & 0.661 & 0.398 & 16 & 0.698 & 0.363 & 8 & 0.729 & 0.715 & 8 & 0.757 & 0.890 \\
\hline & 0.94 & 32 & 0.699 & 0.225 & 16 & 0.735 & 0.368 & 8 & 0.759 & 0.713 & 8 & 0.792 & 0.895 \\
\hline & 0.96 & 32 & 0.743 & 0.227 & 16 & 0.774 & 0.372 & 16 & 0.797 & 0.392 & 8 & 0.828 & 0.897 \\
\hline & 0.98 & 64 & 0.798 & 0.132 & 32 & 0.823 & 0.212 & 16 & 0.843 & 0.406 & 16 & 0.867 & 0.536 \\
\hline & 0.99 & 128 & 0.830 & 0.078 & 32 & 0.851 & 0.217 & 32 & 0.868 & 0.233 & 16 & 0.894 & 0.576 \\
\hline & 0.996 & 128 & 0.852 & 0.080 & 64 & 0.871 & 0.130 & 32 & 0.886 & 0.241 & 16 & 0.910 & 0.599 \\
\hline
\end{tabular}

1. táblázat. Optimalizált fotonszámfeloldó detektorokkal felszerelt bináris időbeli multiplexelésen alapuló egyfotonforrások. Az elérhető $P_{1, \max }^{\mathrm{EFD}}$ maximális egyfoton-valószínúségeket a hozzájuk tartozó $N_{\text {opt }}$ optimális rendszermérettel és $\lambda_{\text {opt }}$ optimális átlagos bemeneti fotonszámmal tüntettük fel $V_{\text {re }}$ reflexiós, $V_{t}$ transzmissziós koefficiensek, valamint különböző $V_{D}$ detektorhatásfokok mellett. Az egyfoton-detektálás (EFD) az $S=\{1\}$ detektálási stratégiát jelöli. A táblázatban $V_{b}=1$ alaptranszmissziót, valamint $V_{p}=0.95$ terjedési veszteséget feltételeztünk.

A detektorhatásfok növelésével ugyanakkor az optimális rendszerméret csökken, az átlagos bemenő fotonszám optimális értéke pedig növekszik. Ennek az az oka, hogy növekvő hatásfok mellett a detektorok egyre inkább képesek kiszúrni azokat a lekonverziós eseményeket, amikor egyetlen fotonpár keletkezik. Az optimális rendszerméretrôl eddig elmondottakat szemlélteti a 2. ábra, ahol bal oldalon rögzített $V_{t}=0.97$ érték mellett ábrázoltuk $\log _{2}\left(N_{\mathrm{opt}}\right)$ értékét $V_{D}$ és $V_{\text {re }}$ függvényében, jobb 
oldalon pedig rögzített $V_{\text {re }}=0.996$ érték mellett $V_{D}$ és $V_{t}$ függvényében.
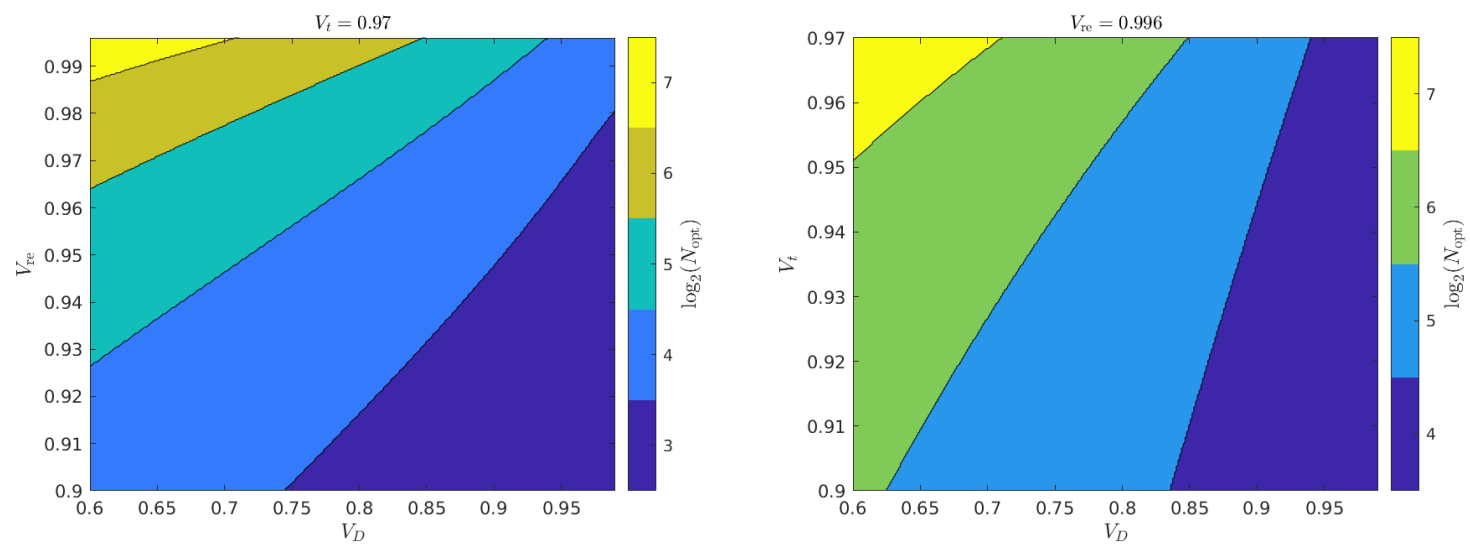

2. ábra. Az időbeli multiplexerben használt szintek optimális száma $\left(\log _{2} N_{\mathrm{opt}}\right)$ a $V_{D}$ detektorhatásfok és a routerre jellemző $V_{\text {re }}$ reflexiós koefficiens (balra), illetve a $V_{t}$ transzmissziós koefficiens (jobbra) függvényében. Az ábrákon a terjedési veszteség értéke $V_{p}=0.95$, a bal oldali ábrán a router transzmissziós koefficiense $V_{t}=0.97$, a jobb oldali ábrán a router reflexiós koefficiense $V_{\mathrm{re}}=0.996$.

A táblázatban vizsgált tartományon az egyfoton-valószínúségek $0.587 \leq P_{1, \max } \leq 0.91$ között változnak. Összehasonlításképpen, $V_{D}=0.98$ hatásfokú küszöbdetektor alkalmazása mellett, az elérhetô legjobb kísérleti paramétereket feltételezve $\left(V_{\mathrm{re}}=0.996, V_{t}=0.97, V_{p}=0.95\right) P_{1, \max }^{\mathrm{KD}}=0.857$ maximális egyfoton-valószínúséget érhetnénk el $N_{\mathrm{opt}}=128$ multiplexelt idôablakkal. Ugyanezen paraméterekkel a táblázatból látható, hogy fotonszámfeloldó detektorral $P_{1, \max }=0.91$ egyfotonvalószínúség érhetô el mindössze $N_{\text {opt }}=16$ multiplexelt időablakkal.

A multiplexelt források kísérleti megvalósításának szempontjából a fotonszámfeloldó detektorok alkalmazásának tehát az az előnye, hogy képesek növelni az elérhető maximális egyfoton-valószínúséget, kisebb rendszerméret mellett. A vizsgált idóbeli multiplexer esetében a kisebb rendszerméret költséghatékonyság melletti további előnye, hogy a forrás ismétlési frekvenciája is nagyobb lehet.

Ahogy korábban említettük, a táblázatban vizsgált tartomány egészén az $S=\{1\}$ az optimális
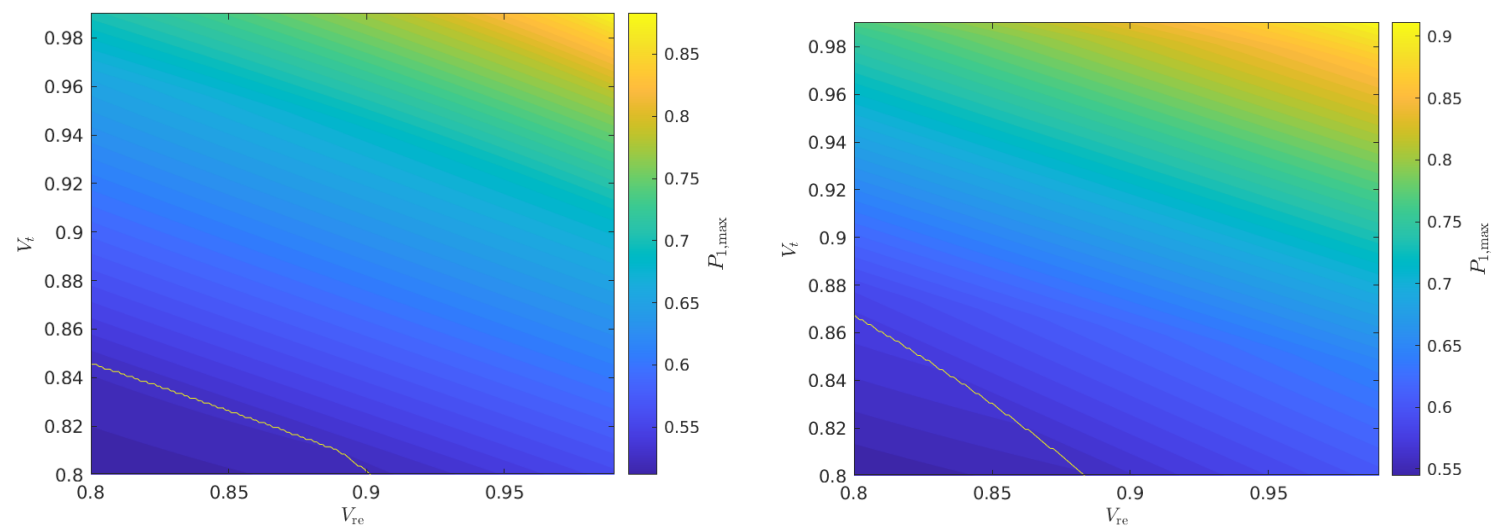

3. ábra. A $P_{1, \max }$ maximális egyfoton-valószínűség a polarizációs nyalábosztó paramétereinek, azaz a $V_{\text {re }}$ reflexiós és $V_{t}$ transzmissziós koefficienseknek a függvényében. A folytonos vonal az optimális detektálási stratégiákat választja el: a vonal felett az egyfoton-detektálás, a vonal alatt a maximum két foton detektálása az optimális. Az ábrák paraméterei: a terjedési veszteséget jellemző koefficiens $V_{p}=0.95$, a detektorhatásfok $V_{d}=0.8$ (balra), $V_{d}=0.98$ (jobbra). 
detektálási stratégia. A detektálási stratégia viselkedésének megértése érdekében a 3. ábrán kiterjesztettuik a $V_{t}$ és $V_{\text {re }}$ paraméterekben vizsgált tartományt $\left(0.8 \leq V_{t}, V_{\text {re }} \leq 0.99\right)$. Az ábrákon $P_{1, \max }$ értékét ábrázoltuk $V_{\text {re }}$ és $V_{t}$ függvényében különböző, rögzített $V_{D}$ értékekre. Szaggatott vonallal választottuk el az $S=\{1,2\}$, valamint $S=\{1\}$ detektálási stratégiákat. Az ábrákon látható, hogy nagyobb veszteségek esetén (szaggatott vonal alatti terület) érdemes a multiplexelő rendszerbe kettő fotont is beengedni, hiszen ekkor már egyikük az áthaladás során jó eséllyel elveszik. A legmagasabb elérhetô $V_{D}=0.98$ detektorhatásfokot feltételezve, a $V_{\mathrm{re}}=V_{t}=0.8$ paraméterek mellett küszöbdetektorral $P_{1, \max }^{\mathrm{KD}}=0.524, S=\{1\}$ detektálási stratégiával $P_{1, \max }^{\mathrm{EFD}}=0.521, S=\{1,2\}$ detektálási stratégiával pedig $P_{1, \max }^{S_{\mathrm{opt}}}=0.545$ maximális egyfoton-valószínúség érhetô el. Ez azt jelenti, hogy a fotonszámfeloldó detektorok megfelelő konfigurálásával ezen a tartományon is $\Delta_{P}=0.02$ egyfotonvalószínúség növekedés érhetô el.

A közleményben a bináris időbeli multiplexelésen alapuló periodikus egyfotonforrások optimalizálását végeztük el fotonszámfeloldó detektorokat feltételezve. Kísérletileg elérhetô paramétertartományon megmutattuk, hogy fotonszámfeloldó detektorokat alkalmazva magasabb egyfoton-valószínûség érhetô el kevesebb multiplexelt egységgel, mintha a pusztán fotonok jelenlétét rögzíteni képes küszöbdetektorokat alkalmaznánk.

\section{Köszönetnyilvánítás}

A munkát az EFOP-3.6.2-16-2017-00005 számú, „Ultragyors fizikai folyamatok atomokban, molekulákban, nanoszerkezetekben és biológiai rendszerekben" címú projekt és az NKFIH K124351 és 2017-1.2.1-NKP-2017-00001 HunQuTech számú projektjei támogatták.

\section{Hivatkozások}

[1] E. Knill, R. Laflamme és G. J. Milburn, Nature 409, 46 (2001). https://doi.org/10.1038/35051009

[2] C. H. Bennett, G. Brassard, C. Crépeau, R. Jozsa, A. Peres és W. K. Wootters, Phys. Rev. Lett. 70, 1895 (1993). https://doi.org/10.1103/PhysRevLett.70.1895

[3] C. C. Gerry, Phys. Rev. A 59, 4095 (1999). https://doi.org/10.1103/PhysRevA.59.4095

[4] A. L. Migdall, D. Branning és S. Castelletto, Phys. Rev. A 66, 053805 (2002). https://doi.org/10.1103/PhysRevA.66.053805

[5] J. H. Shapiro és F. N. Wong, Opt. Lett. 32, 2698 (2007). https://doi.org/10.1364/OL.32.002698

[6] X. S. Ma, S. Zotter, J. Kofler, T. Jennewein és A. Zeilinger, Phys. Rev. A 83, 043814 (2011). https://doi.org/10.1103/PhysRevA.83.043814

[7] R. J. A. Francis-Jones, R. A. Hoggarth és P. J. Mosley, Optica 3, 1270 (2016). https://doi.org/10.1364/OPTICA.3.001270

[8] T. B. Pittman, B. C. Jacobs és J. D. Franson, Phys. Rev. A 66, 042303 (2002). https://doi.org/10.1103/PhysRevA.66.042303 
[9] J. Mower és D. Englund, Phys. Rev. A. 84, 052326 (2011). https://doi.org/10.1103/PhysRevA.84.052326

[10] R. A. Hoggarth, R. J. A. Francis-Jones és P. J. Mosley, J. Opt. 19, 125503 (2017). https://doi.org/10.1088/2040-8986/aa979e

[11] F. Kaneda és P. G. Kwiat, Sci. Adv. 5, (2019). https://doi.org/10.1126/sciadv.aaw8586

[12] P. Adam, M. Mechler, I. Santa és M. Koniorczyk, Phys. Rev. A 90, 053834 (2014). https://doi.org/10.1103/PhysRevA.90.053834

[13] F. Bodog, P. Adam, M. Mechler, I. Santa és M. Koniorczyk, Phys. Rev. A 94, 033853 (2016). https://doi.org/10.1103/PhysRevA.94.033853

[14] F. Bodog, M. Mechler, M. Koniorczyk és P. Adam, Phys. Rev. A 102, 013513 (2020). https://doi.org/10.1103/PhysRevA.102.013513 